\title{
Expression of Growth Hormone Receptor 1A mRNA is Decreased in Dairy Cows but not in Beef Cows at Parturition
}

\author{
H. Jiang, ${ }^{1}$ M. C. Lucy, ${ }^{2}$ B. A. Crooker, $^{3}$ and W. E. Beal ${ }^{1}$ \\ ${ }_{1}^{1}$ Department of Animal and Poultry Sciences, Virginia Tech, Blacksburg 24061 \\ ${ }^{2}$ Department of Animal Sciences, University of Missouri, Columbia 65211 \\ ${ }^{3}$ Department of Animal Science, University of Minnesota, St. Paul 55108
}

\section{ABSTRACT}

The promoter controlling expression of a major bovine growth hormone $(\mathrm{GH})$ receptor (GHR) mRNA variant, GHR 1A, contains a common DNA element for transcription factors hepatocyte nuclear factor $4 \alpha$ (HNF$4 \alpha$ ), hepatocyte nuclear factor $4 \gamma(\mathrm{HNF}-4 \gamma)$, and chicken ovalbumin transcription factor II (COUP-TFII). Expression of GHR 1A mRNA is decreased in the liver of dairy cows at parturition. The objective of this study was to determine whether reduced expression of GHR $1 \mathrm{~A}$ mRNA in dairy cows at parturition is associated with changed expression of $\mathrm{HNF}-4 \alpha, \mathrm{HNF}-4 \gamma$, or COUP-TFII mRNA. Liver biopsy samples were taken from multiparous Holstein cows 7 to $23 \mathrm{~d}$ before parturition, within $24 \mathrm{~h}$ after parturition (i.e., at parturition), and 8 to $18 \mathrm{~d}$ after parturition, and the relative amounts of GHR 1A, insulin-like growth factor-I (IGF-I), HNF$4 \alpha, \mathrm{HNF}-4 \gamma$, and COUP-TFII mRNA in these samples were measured by ribonuclease protection assays. As expected, expression of GHR 1A, total GHR, and IGFI mRNA was decreased at parturition, compared with that detected prepartum or during the postpartum period. Expression of HNF- $4 \alpha$ and COUP-TFII mRNA was unchanged, but that of HNF- $4 \gamma$ mRNA was increased at parturition. The same study was also conducted in multiparous Angus cows 7 to $23 \mathrm{~d}$ before parturition, at parturition, and 8 to $18 \mathrm{~d}$ after parturition. Neither expression of GHR 1A, total GHR, or IGFI mRNA, nor expression of HNF-4 $\alpha$, COUP-TFII, or HNF- $4 \gamma$ mRNA was changed in the liver of beef cows at parturition. These results together suggest that, at the molecular level, decreased expression of GHR 1A mRNA in the liver of dairy cows at parturition may involve increased expression of HNF- $4 \gamma$ mRNA and that, at the systemic level, decreased expression of GHR $1 \mathrm{~A}$ mRNA is not a direct result of the end of pregnancy, parturition, or the initiation of lactation.

(Key words: cow, growth hormone receptor, liver)

Received September 3, 2004.

Accepted December 2, 2004

Corresponding author: H. Jiang; e-mail: hojiang@vt.edu.
Abbreviation key: COUP-TFII = chicken ovalbumin transcription factor II, GAPDH = glyceraldehyde-3phosphate dehydrogenase, $\mathbf{G H}=$ growth hormone GHR = growth hormone receptor, GHR 1A $=$ growth hormone receptor mRNA variant $1 \mathrm{~A}, \mathrm{HNF}-4 \alpha=$ hepatocyte nuclear factor $4 \alpha, \mathbf{H N F}-\mathbf{4} \gamma=$ hepatocyte nuclear factor $4 \gamma, \mathbf{R P A}=$ ribonuclease protection assay.

\section{INTRODUCTION}

Growth hormone (GH), also called somatotropin, is a pituitary hormone that affects, directly or indirectly, many aspects of growth, metabolism, and lactation in cattle (Etherton and Bauman, 1998). Concentration of GH in the blood changes dramatically in high-producing dairy cows during the periparturient period, or the so-called transition period. Blood GH rises sharply at parturition and remains elevated during the first few weeks of lactation (Bell, 1995; Kobayashi et al., 1999). In contrast, blood insulin-like growth factor-1 (IGF-I), most of which is produced by the liver under the stimulation of GH (Sjogren et al., 1999), decreases at parturition and remains low during early lactation (McGuire et al., 1992; Kobayashi et al., 1999). Given the wellknown ability of GH to stimulate lipolysis and to attenuate glucose uptake by skeletal muscle and gluconeogenesis in the liver (Etherton and Bauman, 1998) and the ability of IGF-I to stimulate protein synthesis in muscle (LeRoith and Roberts, 1993), the increase in GH and decrease in IGF-I in circulation at parturition and during the early postpartum period may be part of the mechanism that partitions nutrients to the mammary gland for lactation in dairy cows.

The mechanism underlying the periparturient changes in blood GH and IGF-I in dairy cows is not clear. Not long ago, it was discovered that expression of IGF-I mRNA and that of a major GH receptor (GHR) mRNA variant named GHR 1A mRNA (GHR 1A), which normally represents $50 \%$ of total GHR mRNA in the liver of cattle (Jiang and Lucy, 2001b), was markedly decreased at parturition (Kobayashi et al., 1999). This finding suggested that the periparturient decreases in blood IGF-I in dairy cattle may be due to 
decreased expression of GHR 1A mRNA and, hence, decreased GH stimulation of IGF-I gene expression in the liver. Further, periparturient increases in blood GH may be the result of reduced negative feedback of IGFI on secretion of GH from the pituitary. Thus, understanding the mechanism by which GHR 1 A expression is reduced in the liver of dairy cows at parturition seems to be critical to understanding the changes in the entire GH-IGF-I axis in dairy cows during the transition period.

In previous studies, we demonstrated that the promoter that directs the transcription of GHR 1A mRNA in the liver of cattle contains a common cis-regulatory DNA element for transcription factors hepatocyte nuclear factor $4 \alpha$ (HNF-4 $\alpha$ ), hepatocyte nuclear factor $4 \gamma$ (HNF-4 $\gamma$ ), and chicken ovalbumin transcription factor II (COUP-TFII), and that binding of each of these transcription factors activates the GHR 1A promoter in cultured cells (Jiang and Lucy, 2001a; Xu et al., 2004). As part of the long-term goal to understand the molecular mechanism by which GHR 1A mRNA expression is decreased in the liver of dairy cows at parturition, we have determined in this study the changes in the expression of HNF- $4 \alpha$, HNF- $4 \gamma$, and COUP-TFII mRNA in the liver of dairy and beef cows during the periparturient period.

\section{MATERIALS AND METHODS}

\section{Animals}

Eighteen multiparous Holstein cows at the University of Missouri dairy farm and 18 multiparous Angus cows at the Virginia Tech Kentland farm were used in this study. The dairy cows before parturition and the beef cows throughout the study were fed ad libitum grass hay and a mixture of corn silage, ground corn, soybean meal, and vitamin-mineral premix that met or exceeded the requirements for lactating dairy (NRC, 2001) and beef (NRC, 1996) cattle. The diet of dairy cows after parturition contained whole cottonseed in addition to the components aforementioned. Following parturition, dairy cows were machine-milked twice daily, whereas beef cows were suckled by their calves.

\section{Collection of Liver Tissue Samples}

Liver biopsy samples were collected from a total of 18 dairy or 18 beef cows, including 6 cows 1 to $3 \mathrm{wk}$ before predicted parturition, 6 cows within $24 \mathrm{~h}$ after parturition, and 6 cows 1 to $3 \mathrm{wk}$ after parturition. The biopsy was performed according to a published protocol (Oxender et al., 1971), using approximately $5 \mathrm{~mL}$ of lidocaine $\mathrm{HCl}$ (Abbott Laboratories, North Chicago, IL) as a local anesthetic. The liver biopsy samples from dairy cows were collected with a 14-ga Tru-Cut biopsy needle (Allegiance, McGraw Park, IL); the liver biopsy samples from beef cows were collected with a Courtney bovine liver biopsy needle (Sontec Instruments, Inc., Englewood, CO). Once collected, liver tissue was frozen in liquid nitrogen and stored at $-80^{\circ} \mathrm{C}$.

\section{RNA Extraction}

Total RNA from liver samples was isolated using TRI reagent (MRC, Cincinnati, OH), according to the manufacturer's instructions. Concentration and quality of the extracted RNA were verified by spectrometry and by electrophoresis on formaldehyde-agarose gels. The RNA samples were stored at $-80^{\circ} \mathrm{C}$ until assayed.

\section{Ribonuclease Protection Assays}

Bovine GHR 1A, IGF-I, and glyceraldehyde-3-phosphate dehydrogenase (GAPDH) cDNA plasmids (Kobayashi et al., 1999) and bovine HNF- $4 \alpha, \mathrm{HNF}-4 \gamma$, and COUP-TFII cDNA plasmids (Xu et al., 2004) were linearized with appropriate restriction enzymes. About 0.5 $\mu \mathrm{g}$ of each linearized plasmid was transcribed in vitro with T7 or SP6 RNA polymerase (depending on the orientation of the cDNA insert in the plasmid) in the presence of $\left[\alpha-{ }^{32} \mathrm{P}\right] \mathrm{CTP}$ to generate antisense riboprobe. The in vitro transcription was carried out using the Riboprobe Combination System kit (Promega, Madison, WI), according to the manufacturer's instructions. After transcription, free $\left[\alpha{ }^{32} \mathrm{P}\right] \mathrm{CTP}$ was removed from the probe by phenol-chloroform extraction and filtration through quick spin Sephadex G-50 columns (Roche Molecular Biochemicals, Indianapolis, IN). Specific activity of the purified probe was estimated by liquid-scintillation counting.

The ribonuclease protection assay (RPA) was carried out using the RPA II kit (Ambion, Austin, TX), according to the manufacturer's instructions. Briefly, 15 $\mu \mathrm{g}$ of total liver RNA, $1 \times 10^{5} \mathrm{cpm}$ of 1 or 2 target mRNA riboprobes, and $1 \times 10^{5} \mathrm{cpm}$ of GAPDH probe were mixed in $20 \mu \mathrm{L}$ of hybridization buffer. The mixture was incubated at $42^{\circ} \mathrm{C}$ for about $16 \mathrm{~h}$ and then digested with $200 \mu \mathrm{L}$ of 1:100 diluted ribonucleases $\mathrm{A}$ and $\mathrm{T}_{1}$ at $37^{\circ} \mathrm{C}$ for $30 \mathrm{~min}$. The undigested RNA fragments were precipitated and resolved on $6 \%$ polyacrylamide gels containing $7 M$ urea. The gels were dried, exposed to phosphor screens, and scanned on a Molecular Imager FX system (BioRad, Hercules, CA). Intensity of each protected band was measured using the Alpha Imager program (Alpha Innotech Corporation, San Leandro, CA) and was used to represent the abundance of the corresponding mRNA. Intensity of the protected band for GHR 1A, IGF-I, HNF- $4 \alpha$, HNF- $4 \gamma$, or COUP-TFII 
mRNA was adjusted to that of the GAPDH mRNA in the same sample to normalize variations in the start amounts of RNA and variations in performing RPA.

\section{Data Analyses}

The relative amounts of GHR 1A, non-1A GHR, IGFI, HNF- $4 \alpha$, HNF- $4 \gamma$, or COUP-TFII mRNA were compared among prepartum dairy cows, dairy cows at parturition, and postpartum dairy cows, or among prepartum beef cows, beef cows at parturition, and postpartum beef cows using ANOVA followed by Tukey's procedures of SAS (SAS Inst., Inc., Cary, NC). The dairy cow liver HNF- $4 \gamma$ mRNA and GHR 1A mRNA data were further analyzed for a possible relationship by using the regression procedure of SAS. All data were expressed as least squares means \pm standard errors of the means.

\section{RESULTS}

\section{Liver Expression of GHR 1A and IGF-I mRNA in Dairy Cows}

The RPA using a riboprobe containing a 191-bp region of exon 1A, which is specific for GHR 1A mRNA, and a 121-bp region of exons 2 and 3, which was included in all GHR mRNA variants, generated 2 protected bands (Figure 1A), with the longer band (312 bp) corresponding to GHR 1A mRNA, and the shorter band (121 bp) representing the GHR mRNA variants that do not contain exon $1 \mathrm{~A}$ (i.e., non-1A GHR mRNA). The amounts of GHR 1A mRNA in the dairy cows were less $(P<0.05)$ at parturition than during the 8- to 18 -d period before parturition or the 8- to 14-d postpartum period. The amounts of GHR 1A mRNA were not different among cows during the prepartum period and the postpartum period (Figure 1, A and B). The amounts of non-1A GHR mRNA variants were similar prepartum, at parturition, and postpartum (Figure 1, A and B). The amounts of total GHR mRNA (combination of GHR 1A mRNA and non-1A GHR mRNA), tended ( $P=$ 0.07 ) to be less at parturition, compared with that during the prepartum or the postpartum period (Figure 1B). Compared with non-1A GHR mRNA variants or GAPDH mRNA, GHR 1A mRNA amounts seemed to differ among individual cows (Figure 1A).

Similar to the GHR gene, the IGF-I gene also is expressed as mRNA variants, namely class 1 and class 2 IGF-I mRNA that differ in the $5^{\prime}$ end sequence (Wang et al., 2003). The probe in the RPA of IGF-I mRNA corresponded to a region shared by both class 1 and class 2 IGF-I mRNA (Kobayashi et al., 1999), and the RPA, therefore, detected the amount of total IGF-I mRNA. Based on this RPA (Figure 1), dairy cows tended to express less IGF-I mRNA in the liver at parturition than during the 8 - to 18 -d period before parturition $(P=$ $0.08)$ or the 8 - to 14 -d postpartum period $(P=0.06$; Figure 1, A and B).

\section{Liver Expression of HNF-4 $\alpha$, HNF-4 $\gamma$, and COUP-TFII mRNA in Dairy Cows}

The amounts of HNF- $4 \alpha$, HNF- $4 \gamma$, or COUP-TFII mRNA in the liver samples, from which GHR and IGFI mRNA were quantified, also were determined (Figure 2A). Expression of HNF- $4 \alpha$ mRNA or COUP-TFII mRNA in the liver of dairy cows was not different between the 8- to 18-d period before parturition, at parturition, and the 8- to 14-d postpartum period (Figure 2, A and B). Expression of HNF- $4 \gamma$ mRNA, however, was increased $(P<0.01)$ from the prepartum period to parturition and decreased $(P<0.05)$ from parturition to the postpartum period (Figure 2, A and B). A regression analysis further revealed that liver expression of HNF$4 \gamma$ mRNA was correlated negatively $(P<0.01)$ with that of GHR 1A mRNA in dairy cows during the periparturient period (Figure 2C).

\section{Liver Expression of GHR 1A and IGF-I mRNA in Beef Cows}

The amounts of GHR 1A mRNA in the liver of beef cows during the 7- to 23-d period before parturition, at parturition, and during the 8- to 18-d postpartum period were quantified by RPA (Figure $3 \mathrm{~A}$ ). The RPA revealed that, unlike in dairy cows, the amounts of GHR $1 \mathrm{~A}$ or total GHR mRNA were not changed in beef cows during the 3 periods studied (Figure 3, A and B). As in dairy cows, however, GHR 1A mRNA also appeared to differ among individual beef cows (Figure 3A). Consistent with unchanged GHR mRNA expression, expression of IGF-I mRNA in the liver of beef cows also was unchanged during the periparturient period (Figure 3, $\mathrm{A}$ and $\mathrm{B})$.

\section{Liver Expression of HNF-4 $\alpha$, HNF-4 $\gamma$, and COUP-TFII mRNA in Beef Cows}

Liver expression of HNF- $4 \alpha$, HNF- $4 \gamma$, and COUPTFII mRNA in the same beef cows, from which the amounts of GHR and IGF-I mRNA were quantified (Figure 3), also was determined by RPA (Figure 4). As GHR and IGF-I mRNA, expression of HNF- $4 \alpha, \mathrm{HNF}-4 \gamma$, and COUP-TFII mRNA in the liver of beef cows was unchanged during the periparturient period (Figure 4, A and $\mathrm{B})$.

\section{DISCUSSION}

Transcription of the GHR gene in cattle (Jiang et al., 1999, 2000; Jiang and Lucy, 2001b) as well as in several 


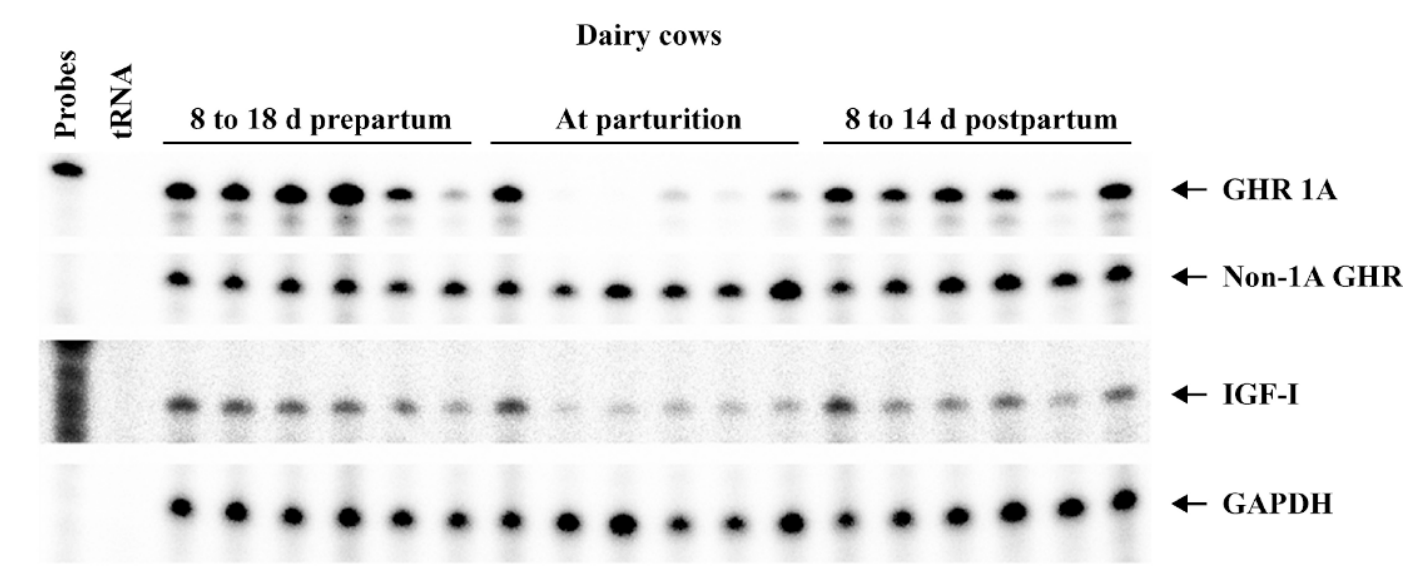

B
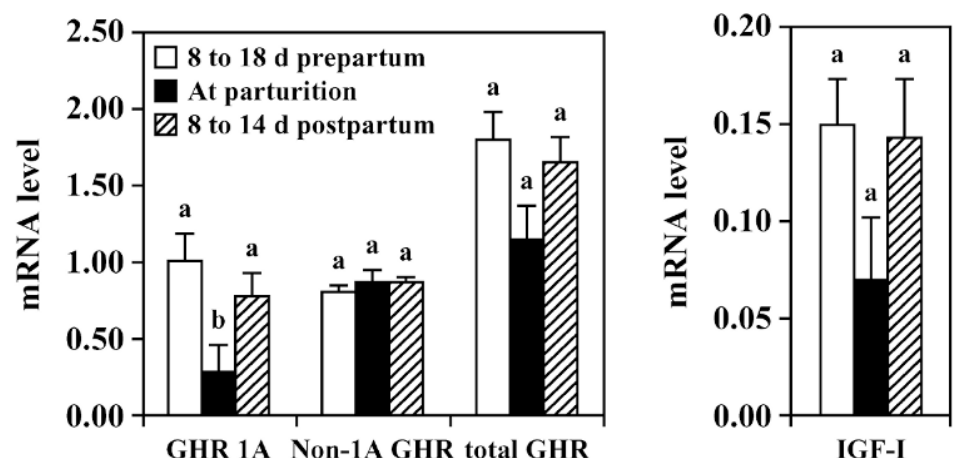

Figure 1. Ribonuclease protection assays (RPA) of growth hormone receptor 1A (GHR 1A) and insulin-like growth factor-1 (IGF-I) mRNA in the liver of dairy cows 8 to $18 \mathrm{~d}$ before parturition, at parturition, and 8 to $14 \mathrm{~d}$ postpartum. (A) Phosphor images of the RPA. The GHR $1 \mathrm{~A}$ and IGF-I mRNA were measured in 2 separate RPA. The ribonuclease-protected fragments corresponding to specific mRNA are indicated with arrows. In each RPA, glyceraldehyde-3-phosphate dehydrogenase (GAPDH) mRNA also was measured as a loading control (GAPDH mRNA bands from only one RPA are shown). tRNA = yeast transfer RNA. (B) Relative amounts of GHR 1A, non-1A GHR, total GHR (i.e., combination of GHR 1A and non-1A GHR), and IGF-I mRNA. Relative abundance of each mRNA was obtained by densitometric analysis of the RPA images in Figure 1A. The density of each protected mRNA band was normalized by that of GAPDH mRNA measured in the same sample. All values are expressed as means \pm SEM. For each mRNA species, the bars with different letters differed $(P<0.05)$. Total GHR mRNA at parturition tended $(P=0.07)$ to be less than that during the prepartum or the postpartum period. The IGF-I mRNA tended to be less at parturition than during the 8 - to 18 -d period before parturition $(P=0.08)$ and the 8 - to 14 -d postpartum period $(P=0.06)$.

other mammalian species (Edens and Talamantes, 1998) is controlled by multiple promoters at different transcription start sites, generating GHR mRNA variants that differ in the 5'-untranslated region, but still encode the same amino acid sequence. In this study, we found that expression of GHR 1A mRNA, normally representing one-half of the total GHR mRNA in the liver of mature cattle (Jiang and Lucy, 2001b), was decreased at parturition, whereas expression of other GHR mRNA variants was unchanged. These results are consistent with early observations in periparturient dairy cows (Kobayashi et al., 1999), identifying a unique physiological situation, parturition, in which GHR 1A expression is distinctly regulated. The physiological significance of reduced expression of GHR 1A mRNA in the liver of dairy cows is not clear, but given its association with reduced IGF-I mRNA in the liver, decreased IGF-I, and increased GH concentrations in the blood (Kobayashi et al., 1999; Radcliff et al., 2003), reduced expression of GHR 1A mRNA may be an early step of the process that partitions nutrients for milk production in dairy cows during the transition period.

The intracellular signaling pathway that leads to reduced GHR 1A mRNA expression in liver cells in dairy 
A

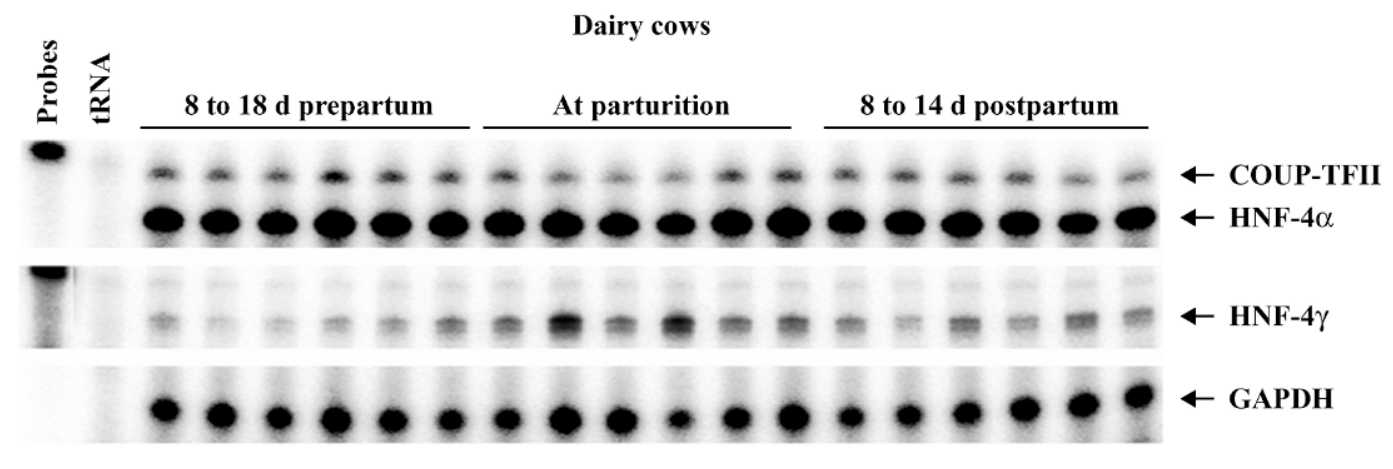

B

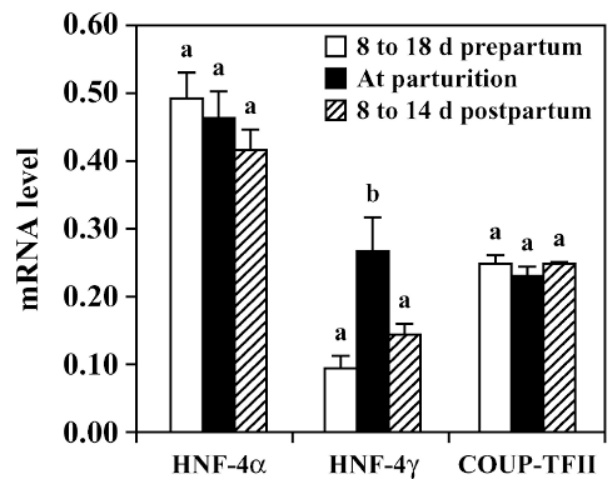

C

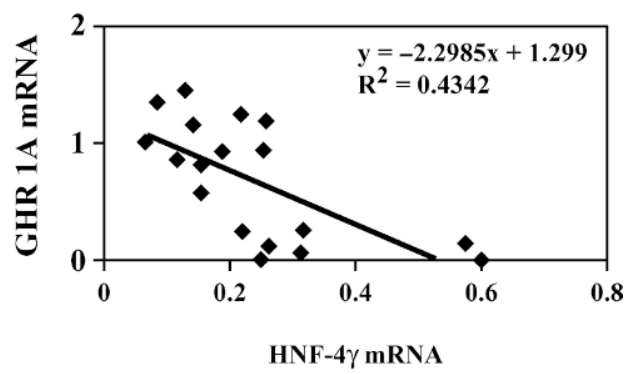

Figure 2. Ribonuclease protection assays (RPA) of hepatocyte nuclear factor $4 \alpha$ (HNF- $4 \alpha$ ), HNF-4 $\gamma$, and chicken ovalbumin transcription factor II (COUP-TFII) mRNA in the liver of dairy cows 8 to $18 \mathrm{~d}$ before parturition, at parturition, and 8 to $14 \mathrm{~d}$ postpartum. (A) Phosphor images of the RPA. tRNA = yeast transfer RNA. (B) Relative amounts of COUP-TFII, HNF- $4 \alpha$, and HNF- $4 \gamma$ mRNA. For each mRNA species, the bars with different letters differed $(P<0.05)$. (C) Negative correlation $(P<0.01)$ was detected between HNF-4 $\gamma$ mRNA and GHR (growth hormone receptor) 1A mRNA amounts in the liver of dairy cows during the periparturient period.

cows at parturition is unknown. In a previous study (Xu et al., 2004), the promoter that transcribes GHR $1 \mathrm{~A}$ mRNA was found to contain a common binding site for liver-enriched transcription factors $\mathrm{HNF}-4 \alpha$ and HNF- $4 \gamma$ as well as for COUP-TFII; binding of each transcription factor to the GHR 1A promoter increases the GHR 1A promoter activity. Therefore, we speculated that a potential cause for decreased expression of GHR $1 \mathrm{~A}$ mRNA in the liver of dairy cows at parturition might be decreased expression of HNF- $4 \alpha$, HNF- $4 \gamma$, or COUPTFII. However, in the present study, we found that mRNA levels of these transcription factors in the liver of dairy cows were not reduced, but, in fact, the amount of HNF- $4 \gamma$ mRNA was increased at parturition. In a recent study (Wook Kim et al., 2004), the protein level of HNF- $4 \alpha$ in the liver of dairy cows was found to be unchanged at parturition. These observations together indicate that decreased GHR 1A mRNA expression in the liver of dairy cows at parturition is not likely caused by reduced expression of HNF- $4 \alpha$ or HNF- $4 \gamma$. Whether the protein level of COUP-TFII is changed at parturition remains to be determined. Changes in promoter activity may also be caused by changes in the DNA binding ability of transcription factors, because of posttranslational modification or interaction with other proteins. Whether the DNA binding ability of HNF- $4 \alpha$, HNF- $4 \gamma$, or COUP-TFII to the GHR $1 \mathrm{~A}$ promoter is reduced in the liver of dairy cows at parturition also remains to be investigated further.

In the present study, we found that reduced expression of GHR 1A mRNA in the liver of dairy cows at parturition was associated unexpectedly with increased expression of HNF- $4 \gamma$ mRNA. In a previous study (Xu et al., 2004), we found that although HNF- $4 \gamma$ can increase GHR 1A promoter activity, its transactivational potential is much weaker than that of COUP-TFII or HNF- 
A

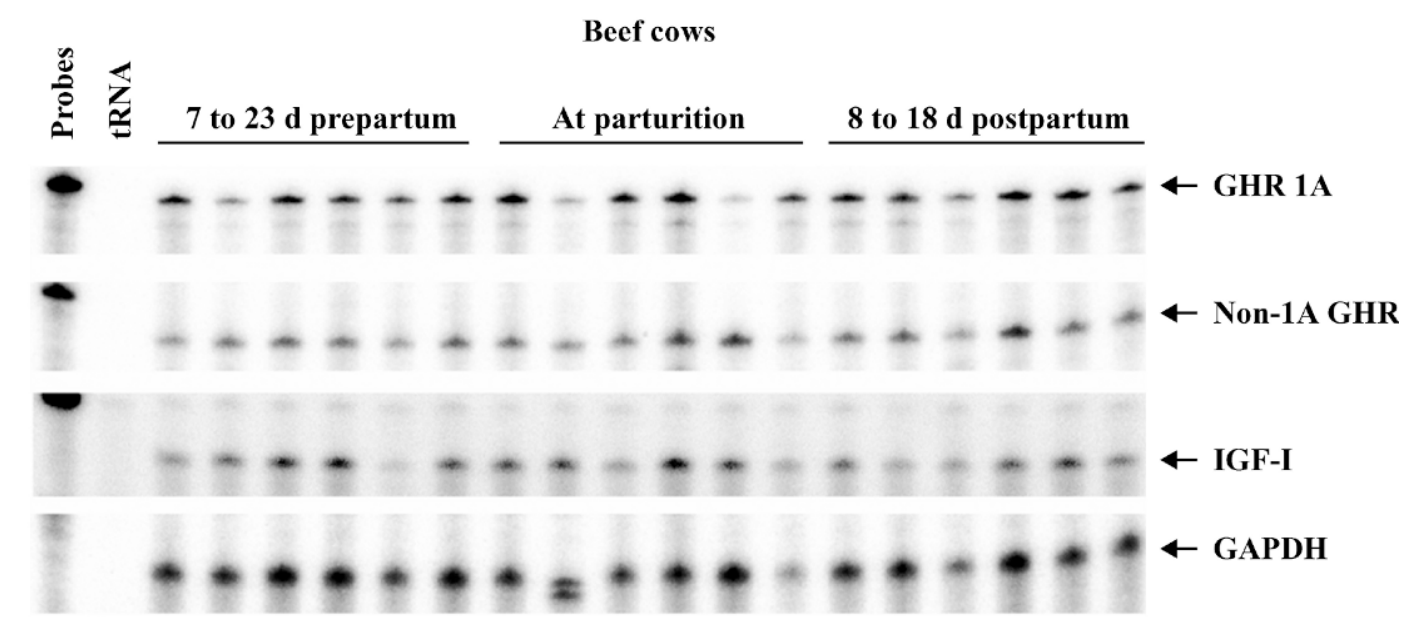

B
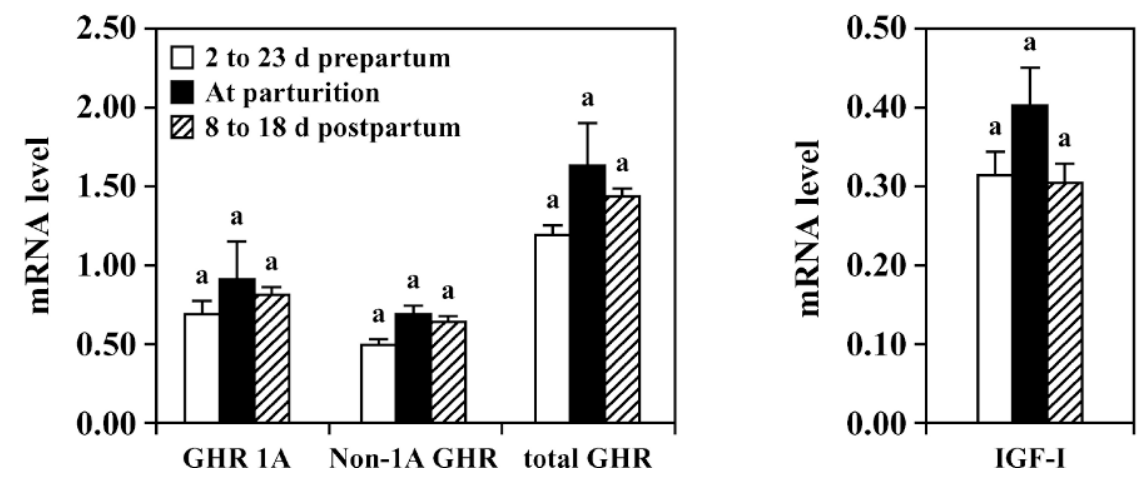

Figure 3. Ribonuclease protection assays (RPA) of growth hormone receptor 1A (GHR 1A) and insulin-like growth factor-1 (IGF-I) mRNA in the liver of beef cows 7 to $23 \mathrm{~d}$ before parturition, at parturition, and 8 to $18 \mathrm{~d}$ postpartum. (A) Phosphor images of the RPA. tRNA = yeast transfer RNA. (B) Relative amounts of GHR 1A, non-1A GHR, total GHR, and IGF-I mRNA. None of these mRNA levels differed ( $P$ $>0.1$ ) between time periods.

$4 \alpha$. That HNF-4 $\gamma$ has less transactivational potential than HNF- $4 \alpha$ has also been reported (Drewes et al., 1996). In a previous study (Xu et al., 2004), we also found that, unlike HNF- $4 \alpha$, HNF- $4 \gamma$ cannot cooperate with COUP-TFII to increase GHR 1A promoter activity. Therefore, it is possible that when HNF- $4 \gamma$ expression is increased, it will compete with the transactivationally stronger COUP-TFII or HNF- $4 \alpha$ for binding to the GHR $1 \mathrm{~A}$ promoter, thereby causing less activation of GHR $1 \mathrm{~A}$ promoter and, hence, decreased expression of GHR 1A mRNA. Such a potential mechanism needs to be tested in future studies. Alternatively, the association between decreased GHR 1A mRNA and increased $\mathrm{HNF}-4 \gamma$ mRNA is coincidental.

Similar to the intracellular signaling pathway, the extracellular factor that acts on the liver cells and causes GHR 1A mRNA expression to decrease in dairy cows at parturition also is unclear. Because reduced GHR 1A mRNA expression occurs at parturition, it has long been suspected that this extracellular factor is a hormone that is closely linked to the end of pregnancy, parturition, or the initiation of lactation, and whose levels vary significantly during the periparturient period (Kobayashi et al., 1999; Radcliff et al., 2003). In our study, we found that unlike their expression in dairy cows, liver expression of GHR 1A, total GHR, and IGF-I mRNA was unchanged during the periparturient period in beef cows. Accompanying unchanged liver GHR and IGF-I mRNA, blood concentrations of IGF-I and $\mathrm{GH}$ also were unchanged in beef cows at parturition (data not shown). Differential expression of GHR 1A mRNA between dairy and beef cows at parturition sug- 
A

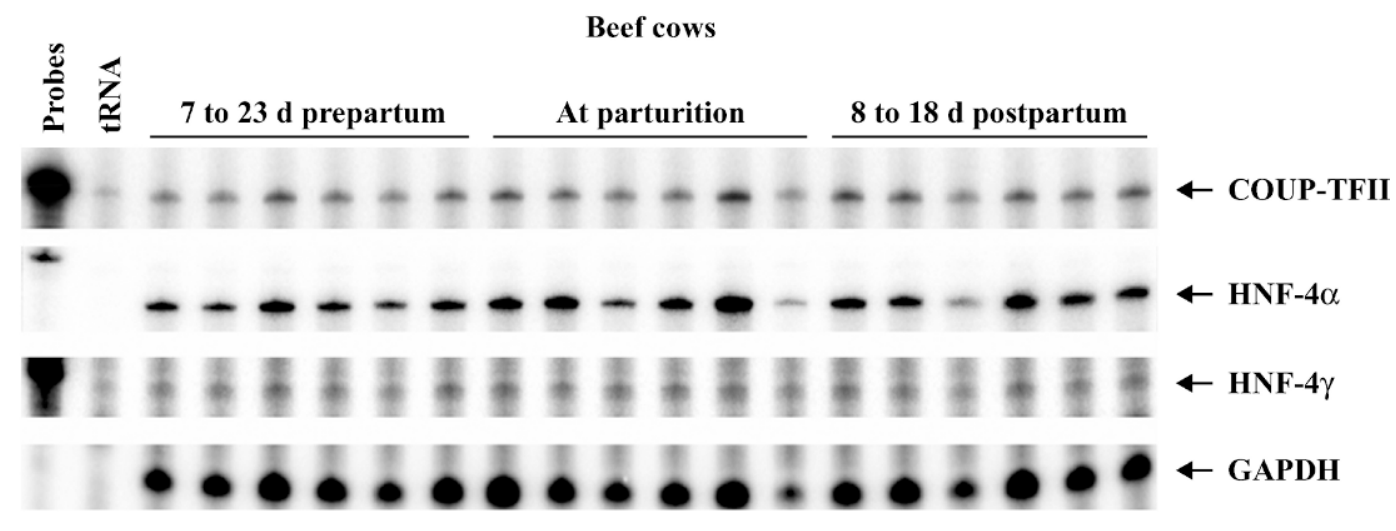

B

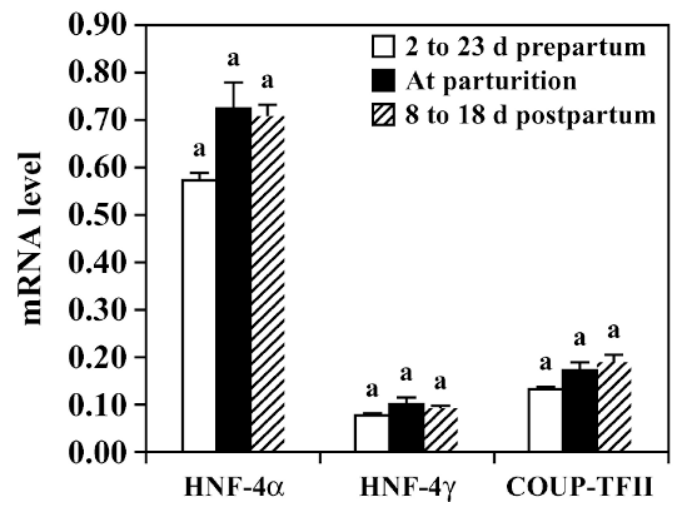

Figure 4. Ribonuclease protection assays (RPA) of hepatocyte nuclear factor $4 \alpha$ (HNF- $4 \alpha$ ), HNF-4 $\gamma$, and chicken ovalbumin transcription factor II (COUP-TFII) mRNA in the liver of beef cows 7 to $23 \mathrm{~d}$ before parturition, at parturition, and 8 to $18 \mathrm{~d}$ postpartum. (A) Phosphor images of the RPA. tRNA = yeast transfer RNA. (B) Relative amounts of COUP-TFII, HNF-4 $\alpha$, and HNF- $4 \gamma$ mRNA. None of these mRNA levels differed $(P>0.1)$ between time periods.

gests that the extracellular signal leading to reduced expression of GHR 1A mRNA in the liver is probably not directly related to the end of pregnancy, parturition, or the initiation of lactation, because these events are experienced by both dairy and beef cows during the periparturient period.

During the periparturient period, dairy cows, and particularly high-yielding dairy cows, are at a negative energy balance because of partitioning of nutrients to the mammary gland and an inability to consume adequate amounts of DM, whereas beef cows and perhaps low-yielding dairy cows too, are believed to be at a positive energy balance because they do not produce as much milk (Hart et al., 1975, 1978; Lukes et al., 1989; Bell, 1995; Block et al., 2001). Negative energy status decreases liver expression of GHR mRNA, including
GHR 1A mRNA, and IGF-I mRNA in cattle (Wang et al., 2003) and in other mammals (Baxter et al., 1981; Straus and Takemoto, 1990; Thissen et al., 1994; Weller et al., 1994). Therefore, it is possible that reduced GHR $1 \mathrm{~A}$ mRNA expression in periparturient dairy cows is the result of the negative energy balance secondary to parturition and lactogenesis. Future research to identify the extracellular signal mediating decreased expression of GHR 1A mRNA in the liver of dairy cows at parturition probably should focus on the role of negative energy balance and related changes in metabolites and metabolic hormones.

In summary, decreased expression of GHR 1A mRNA in the liver of dairy cows at parturition was associated with increased mRNA expression of $\mathrm{HNF}-4 \gamma$ and unchanged mRNA expression of HNF- $4 \alpha$ and COUP-TFII. 
We hypothesize that increased HNF- $4 \gamma$ might compete away the binding of the transactivationally stronger transcription factors COUP-TFII and HNF- $4 \alpha$ to the GHR 1A promoter, thereby decreasing GHR 1A mRNA expression in the liver. Unlike that in dairy cows, liver expression of GHR 1A mRNA in beef cows is not decreased at parturition. These differences between dairy and beef cows indicate that reduced expression of GHR $1 \mathrm{~A}$ mRNA in the liver of dairy cows at parturition is probably not a direct consequence of the termination of pregnancy, parturition, or the initiation of lactation.

\section{ACKNOWLEDGMENTS}

The authors thank S. Price for her excellent technical assistance. The work was supported in part by National Research Initiative Competitive Grant USDA CSREES 2001-35205-11732 awarded to H. Jiang.

\section{REFERENCES}

Baxter, R. C., J. M. Bryson, and J. R. Turtle. 1981. The effect of fasting on liver receptors for prolactin and growth hormone. Metabolism 30:1086-1090.

Bell, A. W. 1995. Regulation of organic nutrient metabolism during transition from late pregnancy to early lactation. J. Anim. Sci. 73:2804-2819.

Block, S. S., W. R. Butler, R. A. Ehrhardt, A. W. Bell, M. E. Van Amburgh, and Y. R. Boisclair. 2001. Decreased concentration of plasma leptin in periparturient dairy cows is caused by negative energy balance. J. Endocrinol. 171:339-348.

Drewes, T., S. Senkel, B. Holewa, and G. U. Ryffel. 1996. Human hepatocyte nuclear factor 4 isoforms are encoded by distinct and differentially expressed genes. Mol. Cell. Biol. 16:925-931.

Edens, A., and F. Talamantes. 1998. Alternative processing of growth hormone receptor transcripts. Endocr. Rev. 19:559-582.

Etherton, T. D., and D. E. Bauman. 1998. Biology of somatotropin in growth and lactation of domestic animals. Physiol. Rev. 78:745-761.

Hart, I. C., J. A. Bines, C. C. Balch, and A. T. Cowie. 1975. Hormone and metabolite differences between lactating beef and dairy cattle. Life Sci. 16:1285-1291.

Hart, I. C., J. A. Bines, S. V. Morant, and J. L. Ridley. 1978. Endocrine control of energy metabolism in the cow: Comparison of the levels of hormones (prolactin, growth hormone, insulin and thyroxine) and metabolites in the plasma of high- and low-yielding cattle at various stages of lactation. J. Endocrinol. 77:333-345.

Jiang, H., and M. C. Lucy. 2001a. Involvement of hepatocyte nuclear factor-4 in the expression of the growth hormone receptor $1 \mathrm{~A}$ messenger ribonucleic acid in bovine liver. Mol. Endocrinol. 15:1023-1034.

Jiang, H., and M. C. Lucy. 2001b. Variants of the 5'-untranslated region of the bovine growth hormone receptor mRNA: Isolation, expression and effects on translational efficiency. Gene 265:4553.
Jiang, H., C. S. Okamura, C. K. Boyd, and M. C. Lucy. 2000. Identification of $\mathrm{Sp} 1$ as the transcription factor for the alternative promoter P2 of the bovine growth hormone receptor gene. J. Mol. Endocrinol. 24:203-214.

Jiang, H., C. S. Okamura, and M. C. Lucy. 1999. Isolation and characterization of a novel promoter for the bovine growth hormone receptor gene. J. Biol. Chem. 274:7893-7900.

Kobayashi, Y., C. K. Boyd, C. J. Bracken, W. R. Lamberson, D. H. Keisler, and M. C. Lucy. 1999. Reduced growth hormone receptor (GHR) messenger ribonucleic acid in liver of periparturient cattle is caused by a specific down-regulation of GHR 1A that is associated with decreased insulin-like growth factor I. Endocrinology 140:3947-3954.

LeRoith, D., and C. T. Roberts, Jr. 1993. Insulin-like growth factors. Ann. NY Acad. Sci. 692:1-9.

Lukes, A. J., M. A. Barnes, and R. E. Pearson. 1989. Response to selection for milk yield and metabolic challenges in primiparous dairy cows. Domest. Anim. Endocrinol. 6:287-298.

McGuire, M. A., J. L. Vicini, D. E. Bauman, and J. Veenhuizen. 1992. Insulin-like growth factors and binding proteins in ruminants and their nutritional regulation. J. Anim. Sci. 70:2901-2910.

National Research Council. 1996. Nutrient Requirements of Beef Cattle. 7th rev. ed. Natl. Acad. Sci., Washington, DC.

National Research Council. 2001. Nutrient Requirements of Dairy Cattle. 7th rev. ed. Natl. Acad. Sci., Washington, DC.

Oxender, W. D., E. W. Askew, J. D. Benson, and R. S. Emery. 1971. Biopsy of liver, adipose tissue and mammary gland of lactating cows. J. Dairy Sci. 54:286-288.

Radcliff, R. P., B. L. McCormack, B. A. Crooker, and M. C. Lucy. 2003. Growth hormone $(\mathrm{GH})$ binding and expression of $\mathrm{GH}$ receptor $1 \mathrm{~A}$ mRNA in hepatic tissue of periparturient dairy cows. J. Dairy Sci. 86:3933-3940.

Sjogren, K., J. L. Liu, K. Blad, S. Skrtic, O. Vidal, C. Wallenius, D. LeRoith, J. Tornell, O. G. Isaksson, J. O. Jansson, and C. Ohlsson. 1999. Liver-derived insulin-like growth factor I (IGF-I) is the principal source of IGF-I in blood but is not required for postnatal body growth in mice. Proc. Natl. Acad. Sci. USA 96:7088-7092.

Straus, D. S., and C. D. Takemoto. 1990. Effect of fasting on insulinlike growth factor I (IGF-I) and growth hormone receptor mRNA levels and IGF-I gene transcription in rat liver. Mol. Endocrinol. 4:91-100.

Thissen, J. P., J. M. Ketelslegers, and L. E. Underwood. 1994. Nutritional regulation of the insulin-like growth factors. Endocr. Rev. 15:80-101.

Wang, Y., S. E. Price, and H. Jiang. 2003. Cloning and characterization of the bovine class 1 and class 2 insulin-like growth factorI mRNAs. Domest. Anim. Endocrinol. 25:315-328.

Weller, P. A., M. J. Dauncey, P. C. Bates, J. M. Brameld, P. J. Buttery, and R. S. Gilmour. 1994. Regulation of porcine insulin-like growth factor I and growth hormone receptor mRNA expression by energy status. Am. J. Physiol. 266:E776-E785.

Wook Kim, J., R. P. Rhoads, S. S. Block, T. R. Overton, S. J. Frank, and Y. R. Boisclair. 2004. Dairy cows experience selective reduction of the hepatic growth hormone receptor during the periparturient period. J. Endocrinol. 181:281-290.

Xu, Q., N. Walther, and H. Jiang. 2004. Chicken ovalbumin upstream promoter transcription factor II (COUP-TFII) and hepatocyte nuclear factor 4 gamma (HNF-4 $\gamma$ ) and $\mathrm{HNF}-4 \alpha$ regulate the bovine growth hormone receptor $1 \mathrm{~A}$ promoter through a common DNA element. J. Mol. Endocrinol. 32:947-961. 